\title{
P3MD Poverty Reduction Program Viewed From the Sharia Economic Perspective
}

\author{
Zakiyah \\ Ekonomi Syariah, Fakultas Studi Islam Uniska MAB \\ kikiayoenani@yahoo.com
}

\begin{abstract}
Since the independence of Indonesia was proclaimed in 1945 until now, it still has problem of economic and social crisis. Indonesian government has not succeeded in establishing a welfare economy and has not been able to build a solid economy for society. The purpose of this research is to find out Poverty Reduction Program in P3MD of Village Economic Development. This is a qualitative research. Method of collecting data used in this research is interview about P3MD in Poverty Reduction through the development of Infrastructure, Education, and Health. Primary data in this study is obtained in the field, the results of interviews with leaders or village apparatus. Secondary data is obtained from document collection related to Poverty Reduction Program. In addition, secondary data is also obtained from library research. The results of this study show the activities in the form of development of facilities and infrastructure such as creativity training, makeup, catfish breeding, making batik, and others can improve economic growth. The concepts of P3MD consist of socialization, negotiation, programming, activity implementation and community participation in Salam Babaris sub district. In the implementation of the P3MD program, the government must determine the policy on the process of distributing the village funds through regional government budget for the development of rural communities in order to be distributed correctly and on time in accordance with village law.
\end{abstract}

Keywords: P3MD, village economic development, negotiation

\begin{abstract}
Abstrak
Semenjak kemerdekaan bangsa Indonesia diproklamasikan pada tahun 1945 hingga saat ini, ternyata perekonomian bangsa Indonesia selalu dilanda krisis ekonomi dan sosial. Pemerintahan di Indonesia yang sekarang berjalan silih berganti ternyata belum mampu membangun sebuah perekonomian kesejahteran dan ternyata belum bisa membangun perekonomian yang kokoh, memakmurkan, mensejahterakan dan adil bagi seluruh rakyat. Tujuan dari penelitian ini untuk mengetahui Program Pengentasan Kemiskinan dalam P3MD pembangunan perekonomian desa. Dalam penelitian menggunakan metode penelitian kualitatif. Dalam metode kualitatif menggunakan pengumpulan data dengan cara wawancara mengenai P3MD dalam pengentasan kemiskinan dengan melalui pembangunan sarana dan prasarana, pendidikan, dan kesehatan. Data primer dalam penelitian ini berupa data yang diperoleh dilapangan, hasil wawancara dengan pimpinan atau pejabat yang ditunjuk dikantor kelurahan dan kecamatan. Sedangkan data sekunder diperoleh melalui studi dokumen terkait dengan Program Pengetasan Kemiskinan. Di samping itu data sekunder juga diperoleh melalui studi kepustakaan (library research) berupa buku panduan, literature kepustakaan dan catatan-catatan yang berhubungan dengan program Perencanaan Partisipasi Pembangunan Masyarakat Desa (P3MD). Hasil dari Penelitian ini menunjukan Program-program kegiatannya berupa pembangunan
\end{abstract}


sarana dan prasarana maupun pembangunan perekonomi lewat kegiatan Bumdesa seperti pelatihan-pelatihan kreativitas seperti tata boga, tata rias, budidaya lele dumbo, membatik, dan lain-lain. Rangkaian konsep perencanaan P3MD terdiri dari sosialisasi, musyawarah program/Musrenbang desa, penyusunan program, pelaksanaan kegiatan dan partisipasi masyarakat di Kecamatan Salam Babaris. Dalam penyelenggaraan program P3MD pemerintah harus menentukan kebijakan mengenai proses pencairan dana desa melalui APBD untuk pembangunan masyarakat desa tertinggal tersalurkan dengan benar dan tepat waktu sesuai dengan ketentuan UU Desa.

Kata Kunci: P3MD, Pembangunan Perekonomian Desa dan Musrenbang Desa.

\section{INTRODUCTION}

Indonesia is a country that has a lot of wealth, yet it has big problem of poverty and unemployment. Poverty is an absolute and relative condition encountered by people in certain regions. It might be caused by nature, culture, and structure that make them unable to fulfill their basic need in accordance with certain prevailing norms available to society (Nugroho \& Dahuri, 2012: 54). Since the independence of Indonesia was proclaimed in 1945 till now, it still has problem of social and economic crisis. The government is still unable to establish good economy to create prosper society. In such phenomenon of poverty, there is no movement of community to overcome the problem in order to widen the prospects and choices to survive and develop in the future, particularly for poor society of city (Basic Training Module of Facilitator PNPM, 2004:8). National program of metropolitan independent society empowerment or commonly known as program of metropolitan poverty precaution is an effort to overcome the problem of poverty through empowerment program as social capital that leads to sustainable development. It means that some projects triggered by the government are expected to be effective ways in overcoming problem of poverty. These programs are supported by society, civil society organizations and many others. After the period of the sixth president's leadership ended, the program changed to plan of development participation of village society.

aParticipative planning of village society development (P3MD, 2016: 20) is a method used to discuss and arrange the plan of development in negotiation of development planning of village level conducted openly and objectively with society. This method is known by some village apparatus; however, it is not practiced anymore as the basic concept and principle of P3MD.

The purpose of village assistance development is to support, enhance and stimulate the potency of village resident in undertaking village development to achieve the purpose of village development, those are:

1. Improving the quality of human resources.

2. Improving the function and role of village apparatus as the village organizer

3. Improving social-economic infrastructure to serve the need of village residents.

4. Improving the urban society economy through the development of productive economy.

The residents' participation in process of decision making, especially develop- 
mental process, is expected that their trust is needed to run the governance in order to be better. Based on the observation by some experts, decentralism could enhance relationship between people and their nation (Training book P3MD: 2016).

Besides, through participation, it can convey people's aspiration by government, including woman aspiration, poor group, and marginal group. Nevertheless, it is confessed that positive impact of decentralism based on some studies is not automatically improving the performance of local government to be better. There are some aspects influencing the success of decentralism namely law working framework, budget policy, transparency and participation.

Local societies actually have an ability to improve themselves by solving the problem and creating their own life. Recently, they are able to analyze the problem, arrange the plan, monitor and evaluate activities well by utilizing human resource they have in holding cooperation with others.

Seeing how big the role of village development through P3MD in overcoming the problem of poverty in Indonesia, the researcher was interested in conducting a research to know the strategy of overcoming the problem used in Salam Berbaris district, Tapin regency viewed from Islamic economics. Based on those phenomena, the researcher would like to discuss more about overcoming of poverty and humans' participation in program of P3MD summarized in a research entitled "P3MD Poverty Reduction Program viewed from Islamic Economics in Salam Berbaris, Tapin Regency".

\section{Theoretical Framework}

\section{Program of P3MD}

Method of P3MD is a method of discussing and developing a development plan in a village that is conducted openly and objectively with the community.

Several constitutions related to Village Development Planning used as a reference are:

1. Law of the Republic of Indonesia Number 25 Year 2004 regarding National Development Planning System.

2. Government Regulation Number 72 Year of 2005 regarding Village.

3. Regulation of home affair minister Number 7 year of 2007 on Community Empowerment Cadres.

4. Regulation of home affair minister Number 19 of 2007 on Training of Community Empowerment and Village.

5. Regulation of home affair minister Number 37 Year of 2007 concerning Guidelines on Village Financial Management.

6. Regulation of home affair minister 66 Year of 2007 on Village Development Planning.

7. Regulation of home affair minister 67 Year of 2007 on Data Collection of Village Development Program.

8. Regulation of home affair minister Number 29 Year of 2006 concerning Guidelines for Establishment and Mechanism of Rural Regulation Formulation.

9. Regulation of home affair minister Number 32 Year of 2006 regarding Village 
Administration Guidelines.

The objectives of P3MD are:

1. Increasing community empowerment and independence so that villagers can participate actively in the process of development management, starting from planning and budgeting.

2. Improving the quality of village development planning based on the study of problems, potency, aspirations and available resources.

3. Increasing the participation of mutual assistance as well as the role and function of community institutions in development that is based on their own ability.

4. Increasing public awareness to use the right of participation in the administration of village government.

\section{The Role of Government in Economic Development}

Government plays a very important role in economic growth for the sake of public prosperity, particularly in fulfilling the primary and secondary needs. The government is in charge of determining fiscal and monetary policies in economic growth. It will trigger growth and working deal, and overcome the problem of poverty (Jusmaliani, 2005: 21).

Policy is a result of decision and action of people with some motivation and information to determine economic policy. Government's role and policy in economy highly depends on the purposes of economy. The main purpose of Islamic economy is to create prosperity and justice and to use the resource optimally. Free working and income collection are the main purposes. There are some roles of government in economic development policy as follow:

a. Policy to reduce poverty

One of important tasks of government in economy is to free the society from poverty problem and to improve their prosperity. The purpose of overcoming poverty is intended to create welfare and fair society. The indicator of prosperity if free from famine and feeling scared. Islamic teaching has mandated that government should actively solve the problem of poverty (Qardhawi, 2000: 41).

b. Policy of prosperity

Islamic principle about fiscal policy and budget aims at improving the society based on wealth distribution and prioritize spiritual and material values. Al Qur'an is the only book in which god commends the right order about policy of nation concerning income and outcome. Fiscal policy is considered as a means to regulate and increase government income (tax, loan, and guarantee toward government outcome). In this theory, tax system used in modern countries proposed the system based on social politic theory, and social advantage for purpose of public prosperity (Qardhawi, 2000: 26).

\section{Poverty Reduction in Islamic Economics}

1. The notion of poverty

Poverty is one of very serious social problems. It means that poverty is a condition in which people are unable to cope with their life problem by themselves based on proper life in a group. They are not capable of utilizing their power either mentally 
or physically in a group (Soekanto, 1994: 42). Poverty mentioned here is the one in economic term, which means the condition of lack of material (Poerwadarminta, 1994).

According to Usman (2003: 37), there are three concepts to understand the meaning of poverty, those are:

a. Absolute poverty, poverty measured based on orientation measurement of minimum basic life need such as clothe, food and house.

b. Relative poverty, poverty based on standard life viewed from dimension of place and time. The basic assumption is poverty in regions different from time of others. The standard of this case is consideration of a group which is oriented to proper life.

c. Subjective poverty, poverty which is formulated based on the feeling of the poor. It means that people with improper life are not willing to be considered as the poor.

2. Poverty reduction in Islamic economics

Government has frequently overcome the problem of poverty. They try solving this problem by applying two primary development policies, those are:

a. Reducing the number of population under the limit of poverty line

b. Undertaking 8 ways of equity that include income division, spread of development, chance to obtain education, health, working opportunity, business, participation in development, and opportunity to get justice.

According to Islamic teaching, the meaning of the poor is those who struggle to survive, but their income is not sufficient to fulfill their daily need. Qardawi (2000: 46) formulates some ways to overcome problem of poverty as follow:

a. Work

b. Suffice the poor's need

c. $\operatorname{Tax}$

d. Assistance fund

e. Necessity of fulfilling the rights

f. Giving charity

Generally, the problem of overcoming poverty in Islam still counts on the concept of zakat since it is permanent source of zakat that can be utilized to improve public prosperity, especially the poor, so they can live independently without hinging on others.

\section{RESEARCH METHOD}

This study used a qualitative approach. A qualitative research is a process of finding out knowledge using data of interview, book, and journal as a means to find out things we want to know (Margono, 2005: 52). That's why this type of research is classified as descriptive-qualitative research type. Every step is started from planning, formulation, arrangement, observation, and evaluation of research findings. This all involves the research object and subject (Margono, 2005: 54).

\section{Research Location}

This research was conducted in Salam Berbaris Village, Tapin Regency, South 
Kalimantan.

\section{Type of Data}

Type of data used in this research consists of two types, namely primary and secondary data. Primary data was taken from interview, and secondary data was taken from documentation result related with poverty reduction program. Besides, secondary data was obtained from library research.

Both primary data and secondary data in this research are from:

a. Interview, first interview was conducted to state institutes of regional government about the process of undertaking P3MD, and the second interview was conducted to society with the intention of figuring out the result of poverty reduction in the perspective of Islamic economics.

b. Field observation, conducted through observing the research object of P3MD, whether it has been conducted according to the principles of Islamic economics.

c. Library research and documentation, conducted with collecting some data from books, journals, report, document and many more.

\section{DISCUSSION}

Sub-district of Salam Berbaris is one of districts located in Tapin Regency, Province of South Kalimantan. The majority of population is farmer and breeder. Based on the data taken in 2015, the number of population was 11.980 which consists of 6.980 male and 4.990 female (www.bps.go.id).

\section{Process of running P3MD Program in Salam Babaris Sub-district in Poverty Reduction}

The problem of poverty is still becoming one of the main issues in Indonesia. To improve the effectiveness of poverty reduction as well as to create employment, the government needs to play a role in fostering the development of village economy by launching the P3MD program in 2016. The P3MD program aims to improve village and economic development, as stated by Fathul Hayati (2016):

"The implementation of P3MD program in Salam Babaris sub district in 2016, I feel happy because I am able to help improve infrastructure and economic development of the village".

The objectives of the P3MD program held in Salam Bebaris sub district are to provide skills, health and entrepreneurship training to bridge communities in order to improve economic growth. P3MD program can help improve economic development in reducing village poverty. There are several stages of development planning through the P3MD Program, those are:

1. The preparation stage of socialization of the P3MD program

In the implementation of P3MD activities, government of Salam Bebaris called the village leaders consisting of village heads, village apparatuses, and community leaders, and then held a socialization of the P3MD program at the sub-district office. In Socializing P3MD Program, the experts of P3MD of Tapin Regency and the 
village facilitators conducted socialization of village programs and budgets for the next one year. The planning of working development is prepared through negotiation among village apparatus. They arranged and discussed about the program in order to reach agreement. According to Duktiy (P3MD Expert), before P3MD program is implemented, there must be socialization of $\mathrm{P} 3 \mathrm{MD}$ program with the aim of preparing any work program needed by the community in Salam Babaris Sub-district in the preparation of P3MD program through negotiation which was conducted every January that refers to document of Village Medium Term Development Plan. Each village is mandated to draw a 5 year plan document, namely Village Medium Term Development Plan and annual plan document.

2. Stage of P3MD Negotiation Program

The concept of negotiation indicates that the negotiation forum is participatory and dialogical between the village government and other stakeholders to discuss and agree on a development program that can advance the village situation. In the process of negotiation, village government and various components of the community work together to think about how to develop their village through village development program (Module Index of Development of Disadvantaged Areas, 2016). As stated by Irfan Rafi'an (2016) as an expert in Tapin Regency of South Kalimantan Province that the purpose of negotiation at the sub district level is to develop the P3MD program for 1 year through negotiation represented by some community leaders.

3. Stage of P3MD Program Implementation

In a study conducted in Salam Babaris Sub district, Tapin District, South Kalimantan Province, the implementation of P3MD program activities was stated from socialization, consultation phase or programming, and implementation step of P3MD program. Based on the results of the research, there are 6 villages, namely Karis Habang Baru, Kambang Habang Lama village, Cabe Beach village, Babaris Salam village, Suato Baru village, and Suato Lama village.

In the implementation of P3MD program, all community members have the same rights to determine the type of programs to be implemented in the villages; this is expressed by Gusti (2016) as community leader. According to him, the village proposed programs to give skill for the sake of development of the village, so that in the implementation of P3MD program, the government activity lasts until the end. In the assistance of P3MD program, the government should pay attention to the purpose and direction of the program that is given to the community. The P3MD program puts forward a participatory planning process. So the villagers develop a program that is needed, then village facilitator accompanies the socialization, preparation of activities programs proposed by citizens and implementation of P3MD program.

\section{Community Participation in P3MD Program}

In the P3MD activities, the community participates in the Working Competition of the P3MD work program in the form of participation to develop facilities and infrastructure. The participation of women groups follow ideas and suggestions of village, and participation in supervision and implementation of P3MD activities. The participation is provided by the community in the form of participation to determine an idea and work program of village to develop village economy.

Participation given to community of Salam Babaris Sub-district is in the form 
energy, cash money, and materials such as cement, sand, stone times, etc. This is of course a major contribution to community participation of P3MD. This is according to Fajar (2016) as the village leader of Tool of Suato, in the activities of participation and assistance in the implementation of P3MD activities. The P3MD program assigns the Local Village Assistant to assist each program implementation. Village negotiation and self-determination is arranged in each village in the form of Village Development Work Plan for 1 year. Usually the P3MD program is supervised and accompanied during the activity is going on, and there are obstacles, then the coordinators usually consult them with the party who is in charge of village activities with the P3MD. So every implementation of P3MD activities, the community participates in the participation of the implementation or in the development of village activities, as well as in the form of ideas or suggestions of village development planning in poverty reduction.

The following is the description of village fund given by the government of Salam Berbaris sub district:

Table 2. Allocation of Village Fund

\begin{tabular}{|c|c|c|c|c|c|c|}
\hline \multirow[t]{2}{*}{ NO } & \multirow[t]{2}{*}{$\begin{array}{l}\text { Name of } \\
\text { Village }\end{array}$} & \multirow[t]{2}{*}{$\begin{array}{l}\text { Allocation } \\
\quad(\mathrm{Rp})\end{array}$} & \multicolumn{2}{|c|}{$\begin{array}{c}\text { Distribution from } \\
\text { regional account to } \\
\text { village account }\end{array}$} & \multicolumn{2}{|c|}{$\begin{array}{l}\text { Distribution to village ac- } \\
\text { count }\end{array}$} \\
\hline & & & Finished & Unfinished & Step I (60\%) & Step II $(40 \%)$ \\
\hline 1. & $\begin{array}{l}\text { Salam } \\
\text { Babaris }\end{array}$ & 620.016 .000 & 1 & 0 & 372.009 .600 & 248.006 .400 \\
\hline 2. & $\begin{array}{l}\text { Suato } \\
\text { Lama }\end{array}$ & 599.148 .000 & 1 & 0 & 359.488 .800 & 239.659 .200 \\
\hline 3. & $\begin{array}{l}\text { Kambang } \\
\text { Habang } \\
\text { Lama }\end{array}$ & 606.766 .000 & 1 & 0 & 364.059 .600 & 242.706 .400 \\
\hline 4. & $\begin{array}{l}\text { Pantai } \\
\text { Cabe }\end{array}$ & 615.174 .000 & 1 & 0 & 369.104 .400 & 246.069 .600 \\
\hline 5. & $\begin{array}{l}\text { Suato } \\
\text { Baru }\end{array}$ & 593.946 .000 & 1 & 0 & 356.367 .600 & 237.578 .400 \\
\hline 6. & $\begin{array}{l}\text { Kambang } \\
\text { Habang } \\
\text { Baru }\end{array}$ & 615.242 .000 & 1 & 0 & 369.145 .200 & 246.096 .800 \\
\hline Sum & 6 Villages & 3.650 .292 .000 & 6 & 0 & 2.190 .175 .200 & 1.460 .116 .800 \\
\hline
\end{tabular}

From the table above, it can be seen that the participation of the community in the Village Community Participation Planning Program in Salam Babaris Subdistrict, Tapin Regency is completed in every activity. Participation will always be available in every level of society in the series of P3MD activities (2016). The fund distributed for the implementation of the program is not only from the P3MD, but also from the community. It can be seen on the Community Development column that there was a large amount of community funds donated for the implementation of the programs they proposed in village. The development of village facilities and infrastructure can 
reduce unemployment and create prosperity of the village economy.

\section{CLOSURE}

Based on the discussion that has been written above, it can be concluded that as follows:

1. The concept of P3MD is a community empowerment program that runs all programs based on the aspirations of the community, and it is absolutely needed by the community. In practice, the program uses community participation in the form of self-help ideas, funds, and power. The activities include the development of facilities, infrastructure and economic development through activities such as training of creativity, makeup, catfish breeding, making batik, and others. The series of P3MD concepts consisted of socialization, regular meetings, programming, implementation of activities and community participation in Salam Berbaris District, Tapin Regency, South Kalimantan.

2. The participation strategy of the village community of Salam Babaris Sub district and the performance of P3MD are done by arranging the planning stages of P3MD implementation activities starting from finding the idea of the village community about what programs are needed by the village community. The role of P3MD Expert, Local Assistant of Village and District companion get involved in the community to find out what programs are needed and what obstacles occur in urban, after that the village apparatus formed a TPK whose purpose is to prepare programs that will be proposed through negotiation among villages in the district. The role of government is determining the performance of the program needed by the community. And the stages of implementation of the activity are supervised by the Local Village Assistant.

\section{SUGGESTION}

Based on the conclusions elaborated above, then the writer would like to give advice as follows:

1. Every activity of P3MD program implementation there must be improvement of performance and supervision of P3MD program to overcome the problem of poverty in Salam Babaris Sub-district, Tapin Regency, South Kalimantan. In the implementation of the P3MD program, the government must determine the policy of the process of disbursing the village funds through the APBD for the development of village. It should be managed correctly and on time in accordance with the provisions of the Village Law.

2. Government should include some processes of participation and community empowerment through training and skills as a medium for society to improve the village economy. During the training activities are carried out, there are only 5 to 7 participants as representatives of each village. The existence of training can improve people's prosperity.

\section{REFERENCES}

Anto. (2001). Prosedur Penelitian: Suatu Pendekatan Praktik Edisi Revisi VI, Jakarta: Rineka 
Cipta

Jusmaliani. (2016). Kebijakan Ekonomi Dalam Islam. Yogyakarta: Kreasi Wacana.

Kementerian Pembangunan Daerah Tertinggal. (2015). Himpunan Peraturan Menteri Desa, Pembangunan Daerah Tertinggal, dan Transmigrasi Republik Indonesia tentang Pedoman tata Tertib dan Mekanisme Pengambilan Keputusan Musyawarah Desa tahun 2015.

Kementerian Desa, Pembangunan Daerah Tertinggal dan Transmigrasi. (2016). Modul Indeks Pembangunan Daerah Tertinggal. Modul Pelatihan Dasar Fasilitator Kelurahan PNPM-P2KP, Konsep PNPM-P2KP, KMW SWK-VI Tahun 2004. Jawa Tengah.

Kementerian Desa, Pembangunan Daerah Tertinggal dan Transmigrasi. . (2016). Panduan Pelatihan P3MD tahun 2016. Jakarta

Kementerian Desa, Pembangunan Daerah Tertinggal dan Transmigrasi. . (2016). Pedoman P3MD (Perencanaan Partisipasi Pembangunan dan Masyarakat Desa). Jakarta

Margono, S. (2005). Metodologi Penelitian Pendidikan. Jakarta: Rineka Cipta.

Nugroho, I., \& Dahuri, R. (2012). Pembangunan wilayah: Presfektif Ekonomi, Social, dan Lingkungan. Jakarta : LP3ES.

Poerwadarminta, W.J.S. (1994). Kamus Umum Bahasa Indonesia, Cet, XVIII. Jakarta: Raja Grafindo Persada.

PP Nomer 72 tahun 2005 tentang pemerintahan desa Permendagri Nomer 66 tahun 2007 tentang perencanaan desa.

Qardhawi, Y. (2000). Teologi Kemiskinan: Doktrin Dasar dan Solusi Islam atas Problema Kemiskinan. Yogyakarta: Mitra Pustaka.

Qardhawi,Y. (2001). Peran Nilai dan Moral Dalam Perekonomian Islam. Jakarta, Robbani Press.

Soekanto, S. (1994). Sosiologi Suatu Pengantar, Cet, XVIII, Jakarta: Raja Grafindo Persada.

Usman, R. (2003). Bank Hijau, Kebijakan Kredit yang Berwawasan Lingkungan. Yogyakarta: Media Pressindo. 